\title{
UTL-5g Lowers Elevated Blood Levels of TNF- $\alpha$ and TGF- $\beta$ and Increases Survival Rates in Animals Treated with LPS/D-(+)-galactosamine
}

\author{
Yiguan Zhang ${ }^{1,2}$, Yongxin Tang ${ }^{2}$, Ben Chen ${ }^{3}$, Frederick Valeriote ${ }^{4}$, Xiaohui Li ${ }^{1}$, Jiajiu Shaw ${ }^{3, *}$ \\ ${ }^{1}$ Institute of Materia Medica \& Department of Pharmaceutics, College of Pharmacy, Third Military Medical \\ University, Chongqing, China \\ ${ }^{2}$ New Phiaring Bio-medical Science Co., Ltd, Chengdu, China \\ ${ }^{3} 21^{\text {st }}$ Century Therapeutics, Ferndale, Michigan, USA \\ ${ }^{4}$ Henry Ford Health System, Detroit, Michigan, USA \\ *Corresponding author: \\ Jiajiu Shaw \\ $21^{\text {st }}$ Century Therapeutics, Inc. \\ Ferndale, Michigan \\ USA \\ Phone 1-248-545-0595 \\ E-mail: jiajiuhaw@gmail.com
}

Received: 29 April 2014; | Revised: 20 May 2014; | Accepted: 8 June 2014

\begin{abstract}
$\mathrm{N}$-(2,4-dichlorophenyl)-5-methyl-1,2-oxazole-3-carboxamide (UTL-5g) is a small-molecule chemoprotector against cisplatin and radioprotector against radiation. To further investigate its protective effects, we evaluated whether UTL-5g protects mice in a septic shock animal model. The two metabolites of UTL-5g, 5-methylisoxazole-3-carboxylic acid (Isox) and 2,4-dichloroaniline (DCA) were also evaluated side-by-side with UTL-5g. First, mice were pretreated with UTL-5g, Isox, and DCA before the i.p. injection of lipopolysaccharide (LPS)/D-(+)-galactosamine hydrochloride (D-Gal), respectively. Oral administration of both UTL-5g and Isox increased mouse survival while DCA did not, indicating that Isox is an active metabolite of UTL-5g while DCA is not. In the second study, mice were pretreated with UTL-5g or Isox individually by i.p. injection each at $30 \mathrm{mg} / \mathrm{kg}$ before LPS/D-Gal injection. The survival rates for both UTL$5 \mathrm{~g}$ and Isox were better than those found for oral administration. In the third study, the same molar dose of UTL-5g and Isox by i.p. injection was used respectively and the results showed that UTL-5g had a better protective effect than Isox. In the fourth study, a protocol similar to the third study was used but blood samples were collected from the orbital plexus two hr after LPS/D-gal treatment. The results showed that UTL-5g lowered blood levels of both TNF- $\alpha$ and TGF- $\beta$ elevated by LPS/D-gal. In summary, pretreatment of UTL-5g protected mice treated with LPS/D-Gal and the protection was related to the lowering of TNF- $\alpha$ and TGF- $\beta$ levels elevated by LPS/D-Gal. In addition, UTL-5g appeared to be both an active drug and a prodrug wherein Isox is the active metabolite.
\end{abstract}

Keywords: UTL-5g, sepsis animal model, LPS/D-Gal, survival, TNF- $\alpha$, TGF- $\beta$. 


\section{Introduction}

Leflunomide is a disease-modifying antirheumatic drug (DMARD) but with significant potential side effects [1-5]. Based on a subtle but critical modification on the molecular scaffold of leflunomide, we designed, synthesized and, studied a series of UTL-5 compounds; several UTL-5 compounds have been shown to be TNF$\alpha$ inhibitors and a particular compound, N-(2,4dichlorophenyl)-5-methyl-1,2-oxazole-3carboxamide (UTL-5g), is under preclinical development [6]. Although structurally similar to leflunomide, UTL-5 compounds have shown significantly different metabolic behaviors [7-9] . Leflunomide is metabolized by microsomes to become its major metabolite, teriflunomide (Fig. 1 ), by opening the isoxazole ring at the $\mathrm{N}-\mathrm{O}$ bond [10]; however, UTL-5 compounds are metabolized by cleavage of the peptide bond but the isoxazole ring remains intact (Fig. 1). For example, UTL-5b is metabolized by rat microsomes to become 5-methylisoxazole-3carboxylic acid (Isox) and 2-chloroaniline [8]; UTL-5g is quickly converted to Isox and 2,4dichloroaniline (DCA) in the presence of esterase [7].

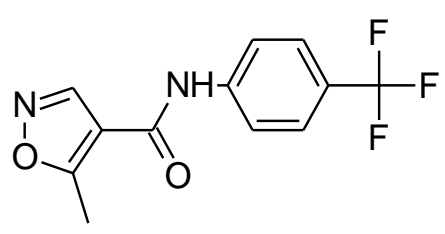

Leflunomide<smiles>Cc1cc(C(=O)Nc2ccccc2Cl)no1</smiles>

UTL-5b

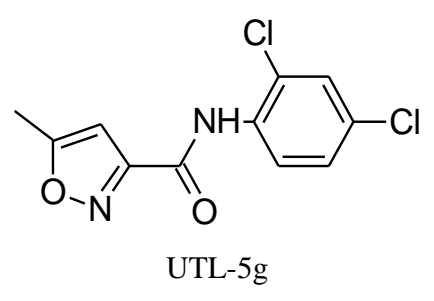

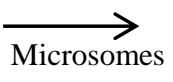
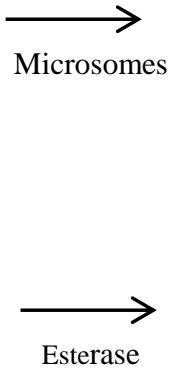

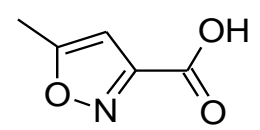

5-methylisoxazole-3-carboxylic acid (Isox)

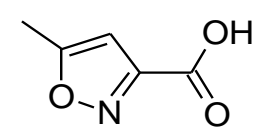

5-methylisoxazole-3-carboxylic acid (Isox)

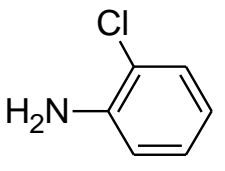

2-chloroaniline<smiles>Nc1ccc(Cl)cc1Cl</smiles>

2,4-dichloroaniline (DCA)

Figure 1. Structures of leflunomide, UTL-5b, $-5 \mathrm{~g}$, and their respective metabolites

In terms of pharmacological effects, UTL-5 compounds are similar to leflunomide in that they are both anti-inflammatory and anti-arthritic [1114]. However, UTL-5 compounds possess some protective effects which are significantly different from those of leflunomide. For example, UTL-5g reduces cisplatin-induced side effects by protecting kidney, liver, and platelets [6], thereby, increasing the tolerability of cisplatin [15]. In addition, UTL-5b and $-5 \mathrm{~g}$ reduce radiation-induced side effects in liver [16]. These pharmacological effects against chemotherapy/ radiation-induced side effects are different from those of leflunomide. For example, lefunomide is associated with certain liver toxicity and FDA issued prescribing warnings about potential hepatotoxicity [17]; in many cases, aspartate transaminase (AST) and alanine transaminase (ALT) levels are elevated [18], whereas UTL-5g 
lowers AST/ALT levels elevated by cisplatin or radiation in our animal studies [6].

Therefore, it is of interest to further investigate the protective effects of UTL-5g and its metabolites. Because UTL-5g is a TNF- $\alpha$ inhibitor and lipopolysaccharide (LPS) is an endotoxin that promotes the secretion of proinflammatory cytokines including TNF- $\alpha$ [19, 20], we investigated whether UTL-5g and/or its metabolites protect mice from the lethal toxicity induced by LPS/D-(+)-galactosamine hydrochloride (D-Gal) in a septic shock animal model [21].

\section{Materials and Methods}

\subsection{Materials}

UTL-5g (HPLC purity >99\%) was provided by $21^{\text {st }}$ Century Therapeutics. Isox, DCA, and LPS were purchased from Sigma-Aldrich and used without further purification. CMC was purchased from Anhui Sunhe Pharmaceutical Excipients Co. (China). UTL-5g, Isox, and DCA were dispersed respectively in $1 \%$ carboxymethyl cellulose (CMC) for the animal treatment; UTL$5 \mathrm{~g}$ and DCA maintained as suspensions in $1 \%$ $\mathrm{CMC}$ but the Isox preparation became a clear solution.

Kunming female mice (3-6 wk, 16-22 g) were purchased from the Third Army Medical University, Animal Testing Center (Chongqing, China). TNF- $\alpha$ Elisa kits were purchased from Ray Biotech (USA); TGF- $\beta$ testing kits were purchased from DaKeWei Biotech, Beijing (China). All other reagents were purchased from Aldrich-Sigma unless otherwise specified.

\subsection{Animal Study}

In the first study, a total of 50 Kunming female mice were randomly divided into 5 groups: (1) vehicle control, (2) LPS/D-Gal, (3) UTL-5g and LPS/D-Gal, (4) Isox and LPS/DGal, (5) DCA and LPS/D-Gal. Isox and DCA were studied because they both are metabolites of UTL-5g [7]. For individual mice in groups 2-5, testing agents (UTL-5g, Isox, and DCA all at 60 $\mathrm{mg} / \mathrm{kg}$ ) were given by oral gavage respectively 1 $\mathrm{hr}$ before given LPS/D-gal $(50 \mu \mathrm{g} / \mathrm{kg}$ and 600 $\mathrm{mg} / \mathrm{kg}$ respectively) by i.p. injection.
In the second study, a total of 40 mice were used and divided into 4 groups: (1) vehicle control, (2) LPS/D-gal, (3) UTL-5g and LPS/DGal, and (4) Isox and LPS/D-Gal. In the control group, only vehicle was injected. For groups 2, 3, and 4 , individual mice in groups were pretreated with corresponding agent $1 \mathrm{hr}$ before given LPS/D-gal $\quad(50 \mu \mathrm{g} / \mathrm{kg}$ and $550 \quad \mathrm{mg} / \mathrm{kg}$ respectively). Different from the first study, Dgal was reduced from 600 to $550 \mathrm{mg} / \mathrm{kg}$; the doses of UTL-5g and Isox were reduced to one half $(30 \mathrm{mg} / \mathrm{kg}$ each) and both were administered by i.p. injection. All animals were monitored for their body weights and survival.

In the third study, 6 groups of mice (10 mice/group) were used: (1) vehicle group, (2) LPS/D-gal, (3) UTL-5g (30 $\mathrm{mg} / \mathrm{kg}$ or 0.11 $\mathrm{mMole} / \mathrm{kg}$ ) and LPS-D-gal, (4) UTL-5g (60 $\mathrm{mg} / \mathrm{kg}$ or $0.22 \mathrm{mMole} / \mathrm{kg}$ ) and LPS/D-gal, (5) Isox $(14 \mathrm{mg} / \mathrm{kg}$ or $0.11 \mathrm{mMole} / \mathrm{kg})$-LPS/D-gal, (6) Isox $(28 \mathrm{mg} / \mathrm{kg}$ or $0.22 \mathrm{mMole} / \mathrm{kg})-\mathrm{LPS} / \mathrm{D}$ gal. UTL-5g and Isox were administered by i.p. injection $1 \mathrm{hr}$ before given $50 \mu \mathrm{g} / \mathrm{kg}$ LPS and 550 $\mathrm{mg} / \mathrm{kg}$ D-gal by i.p. injection. Again, all animals were monitored for their bodyweights and survivals.

In the last study, Kunming female mice (5 mice/group) were treated in the manner identical to the third study, but blood samples were collected from the orbital plexus two hr after LPS/D-Gal treatment. Mouse plasma samples were prepared and stored at $-70{ }^{\circ} \mathrm{C}$ until analyzed by commercially available ELISA kits for levels of both TNF- $\alpha$ and TGF- $\beta$ according to the manufactures' instructions.

\section{Results}

\subsection{Animal study \#1}

As shown in Fig 2a, on Day 1 (24 hr after given LPS/D-gal), in the group without pretreatment, all 10 mice died; in the group pretreated with oral UTL-5g (at $60 \mathrm{mg} / \mathrm{kg}$ ), 1 mouse survived; in the group pretreated with metabolite \#1 (Isox) at $60 \mathrm{mg} / \mathrm{kg}, 4$ mice survived; in the group pretreated with metabolite \#2 (DCA) at $60 \mathrm{mg} / \mathrm{kg}$, all 10 mice died. 
(a)

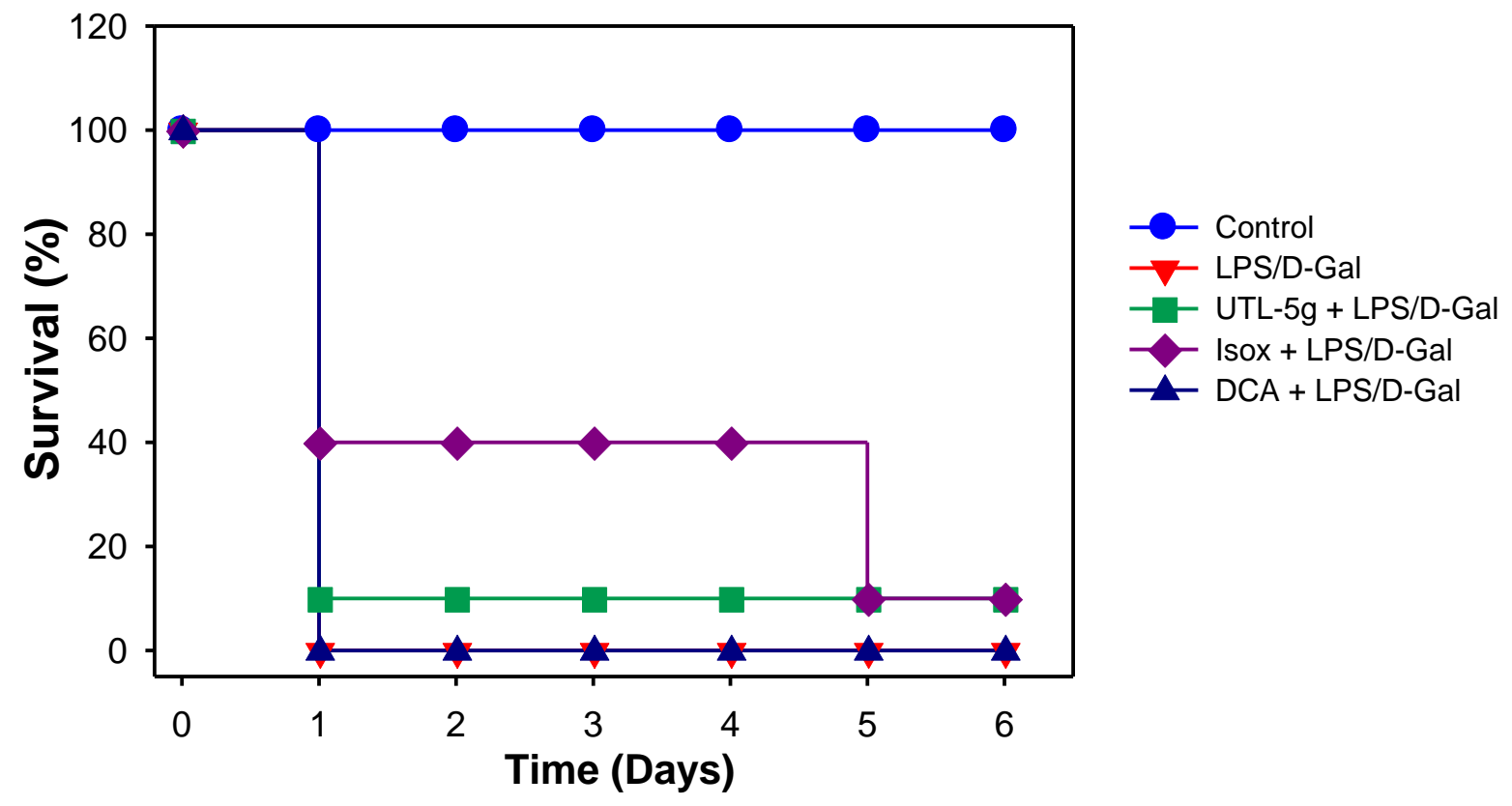

(b)

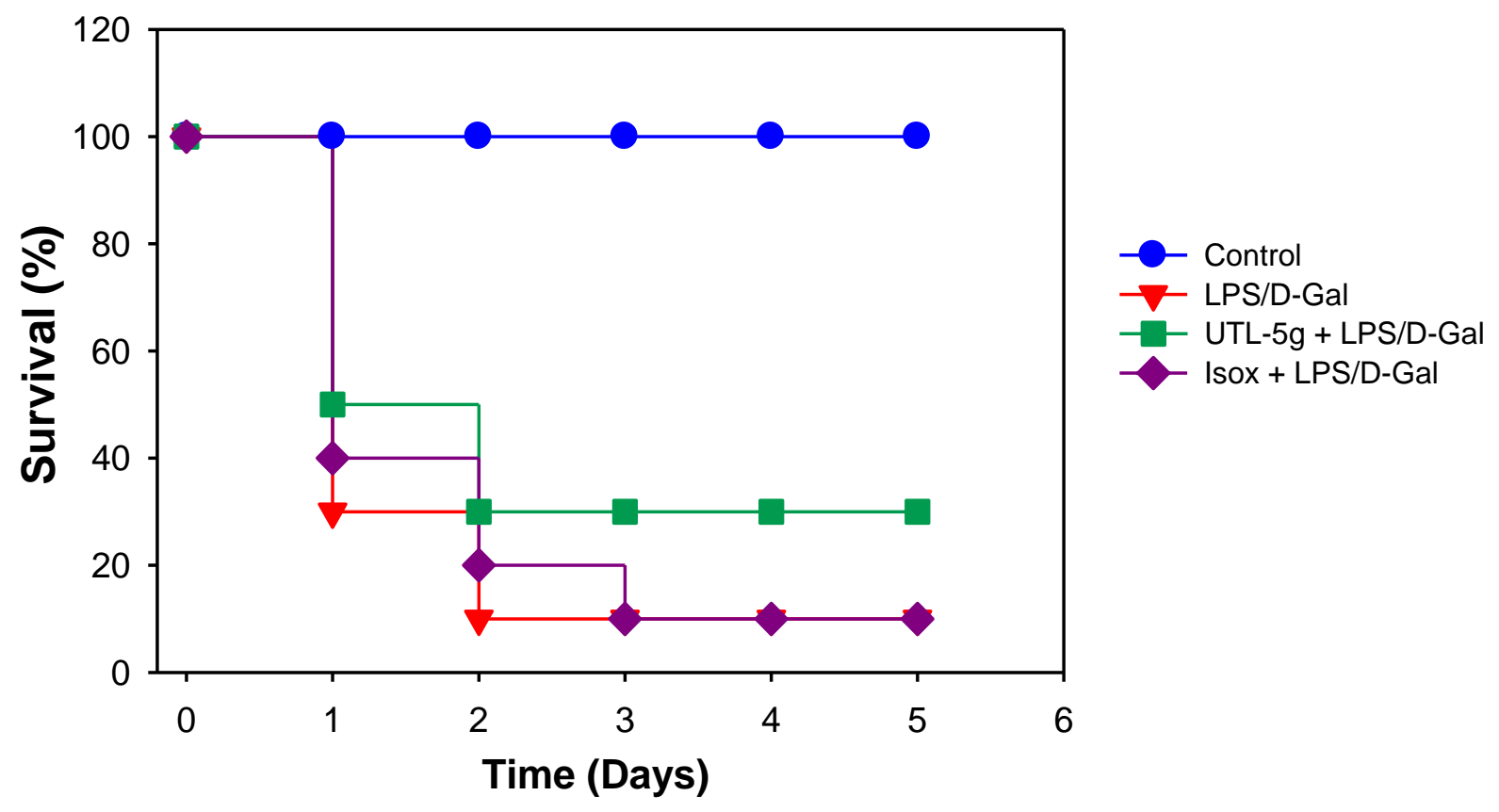

Figure 2. Effects of UTL-5g/Isox pretreatment on mouse survival rates

(a) Mouse survival rates following pretreatment by UTL-5g and Isox (both at $60 \mathrm{mg} / \mathrm{kg}$ ) by oral gavage before LPS/DGal administration $(50 \mu \mathrm{g} / \mathrm{kg}$ and $600 \mathrm{mg} / \mathrm{kg})$; (b) Mouse survival rates following pretreatment by UTL-5g and Isox (both at 30mg/kg) by i.p. injection before LPS/D-Gal administration $(50 \mu \mathrm{g} / \mathrm{kg}$ and $550 \mathrm{mg} / \mathrm{kg})$. 


\subsection{Animal study \#2}

Results from the second study (Fig. 2b), using both UTL-5g and Isox at $30 \mathrm{mg} / \mathrm{kg}$ by i.p. injection, showed that, in the group without pretreatment, 3 mice survived on Day 1 ( $24 \mathrm{hr}$ ), only 1 survived on Day 2, and maintained the same until Day 5. In the UTL-5g group, 5 mice survived on Day 1 (vs. 3 survived in LPS/D-gal group, a 66\% increase in survival rate) and 3 survived on Day 2 (vs. 1 survival in LPS/D-Gal group) and maintained the same until Day 5. In the Isox group, 4 mice survived (vs. 3 survived in LPS/D-gal group, a $33 \%$ increase in survival) on
Day 1, 2mice survived on Day 2 (vs. 1 survival in LPS/D-Gal group), and only 1 survived from Day 3 until Day 5.

As shown in Fig. 3, LPS/D-Gal treatment reduced the average body weights of mice by $7 \%$ on Day 1 and UTL-5g lessened this weight-loss effect to only $3 \%$ on Day 1 . However, Isox did not lessen the weight-loss effect especially after Day 2 although Isox did increase the survival rate slightly; this could be because there was only one mouse survived after Day 2; thus the Isox data was not representative.

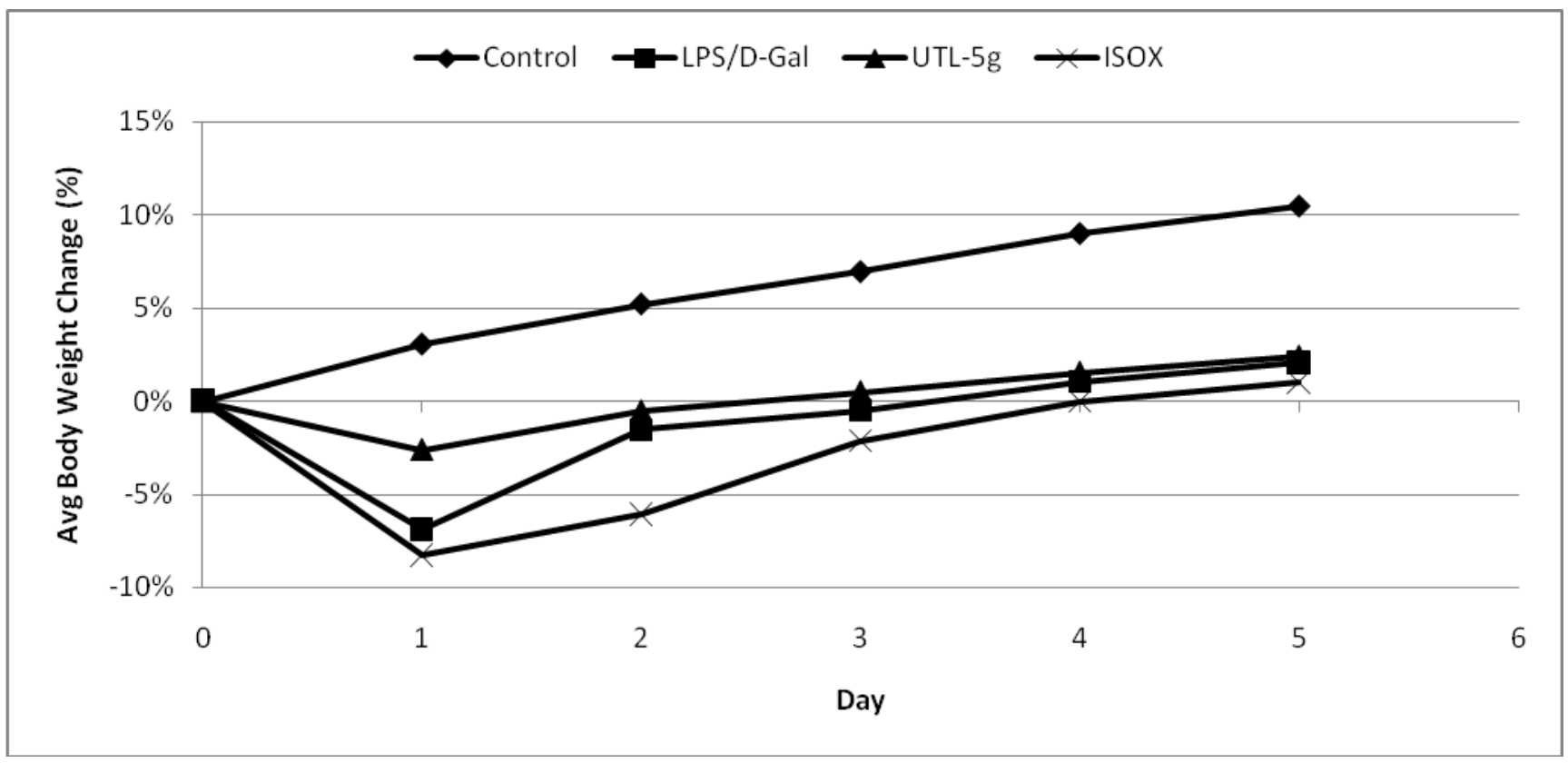

Figure 3. Mouse body weight change vs. time from the second study

Body weight profiles of four groups: (1) vehicle control, (2) LPS/D-Gal, (3) UTL-5g + LPS/D-Gal, and (4) Isox + LPS/D-Gal. UTL-5g and Isox were both given at $30 \mathrm{mg} / \mathrm{kg}$ by i.p. injection. Each data point represents the average of 10 mice on Day 0 and lower numbers (survivals) from Day 1 and after. Standard deviations are not shown to make it easier to distinguish the profiles among these four groups.

\subsection{Animal study \#3}

Results from the third study (Fig. 4) showed that UTL-5g protection of animals from the lethal toxicity was dose dependent in that $5 / 6$ mice survived by UTL-5g pretreatment at $0.11 / 0.22$ $\mathrm{mMole} / \mathrm{kg}$ on Day 1 whereas only 3 mice survived without pretreatment; the survival increase was dose dependent. Fig. 4(a) shows that at a lower dose $(0.11 \mathrm{mMole} / \mathrm{kg}), \mathrm{UTL}-5 \mathrm{~g}$ has a better protective effect as compared to Isox. Fig. 4(b) shows that at $0.22 \mathrm{mMole}$, UTL-5g also has a much better protective effect and resulted in higher survivals.

As to the body weights, Fig. 5 shows that the average weight of the mice in the LPS/D-Gal group was the lowest as compared to all other groups and its nadir is on Day 2. At 0.11 mMole/kg (Fig. 5a), UTL-5g group did not lose 
weight and started to gain weight from Day 2. At $0.22 \mathrm{mMole} / \mathrm{kg}$ (Fig. 5b), UTL-5g group did lose weight but started to recover from Day 2.At both doses (Fig. 5a and 5b), mice in Isox group lost some weights on Day 1 and 2, but started to gain back from Day 3.

(a)

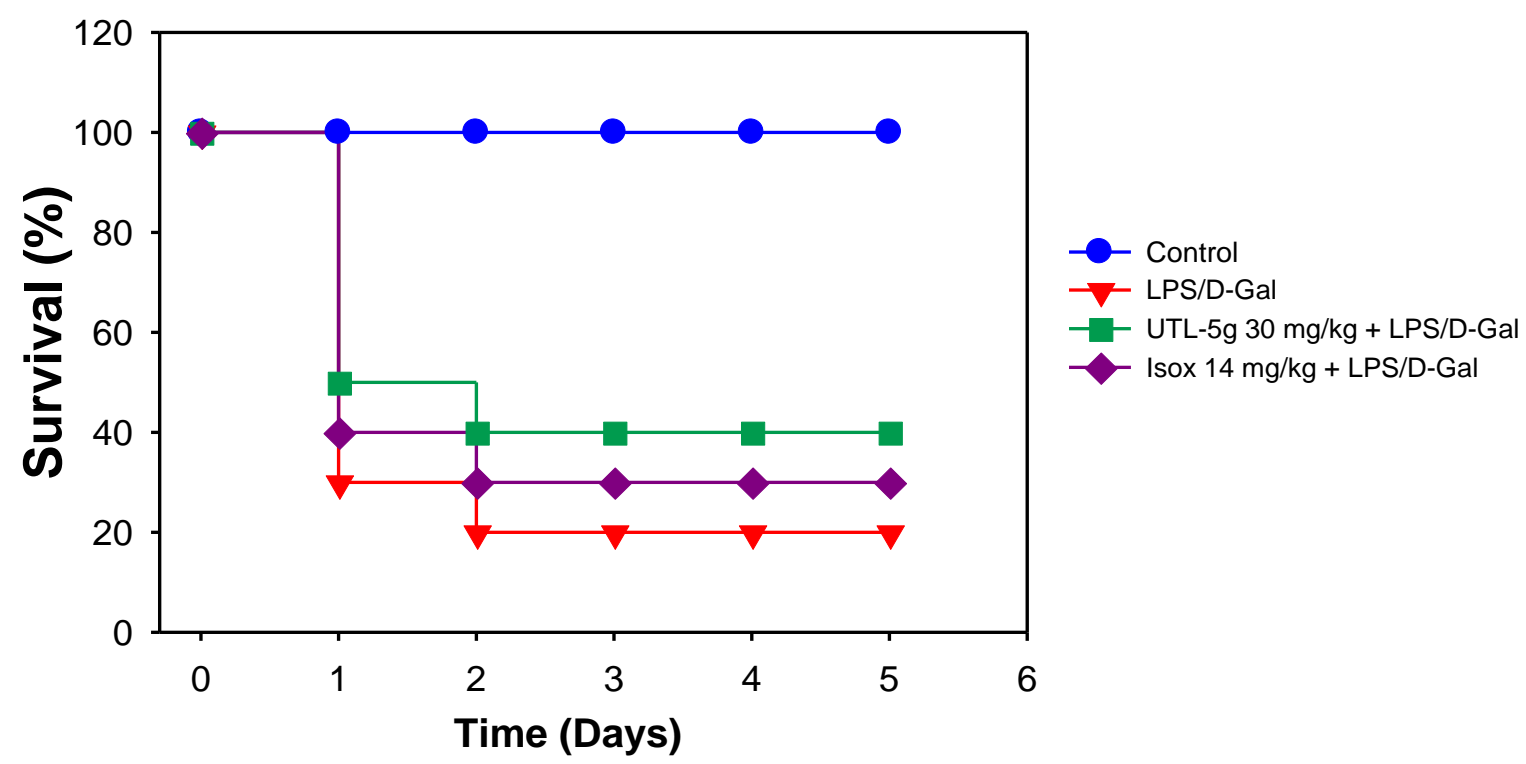

(b)

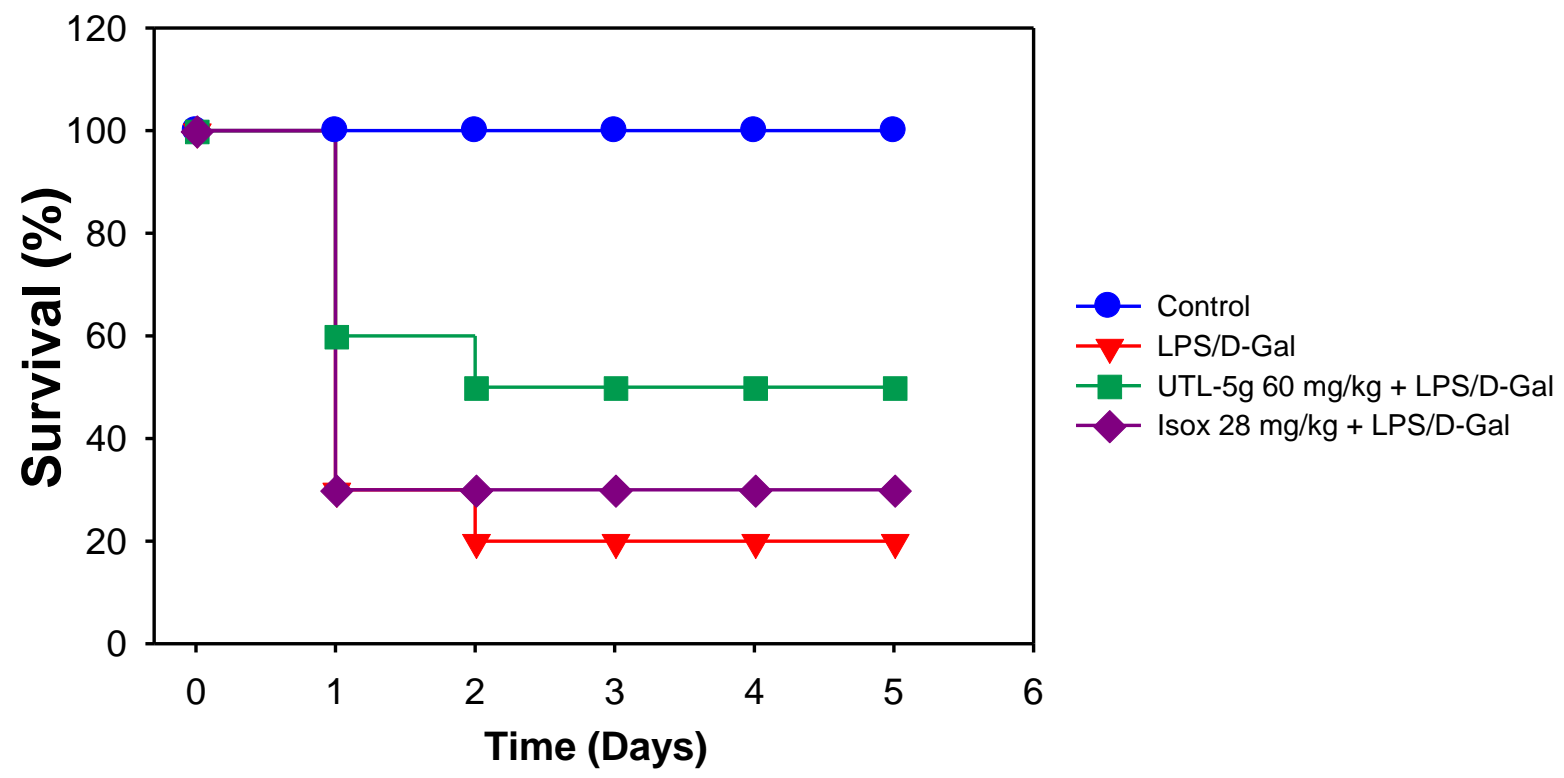

Figure 4. Survival rates with the pretreatment of UTL-5g and Isox at the same molar dose by i.p. injection (a) UTL-5g and Isox both at $0.11 \mathrm{mMole} / \mathrm{kg}$ (UTL-5g at $30 \mathrm{mg} / \mathrm{kg}$ vs. Isox at $14 \mathrm{mg} / \mathrm{kg}$ ); (b) UTL-5g and Isox both at $0.22 \mathrm{mMole} / \mathrm{kg}$ (UTL-5g at $60 \mathrm{mg} / \mathrm{kg}$ vs. Isox at $28 \mathrm{mg} / \mathrm{kg}$ ). 
(a)

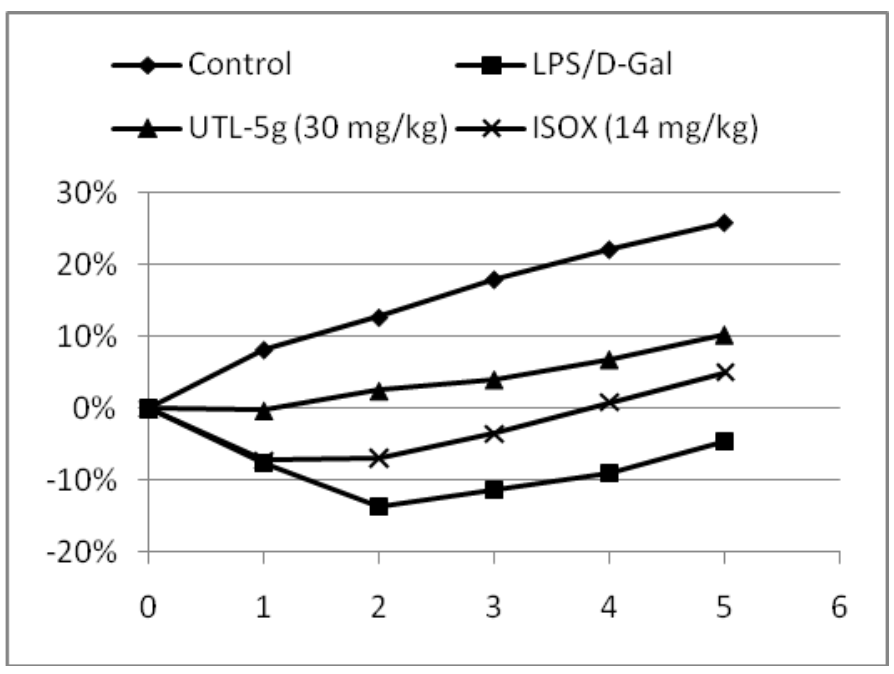

(b)

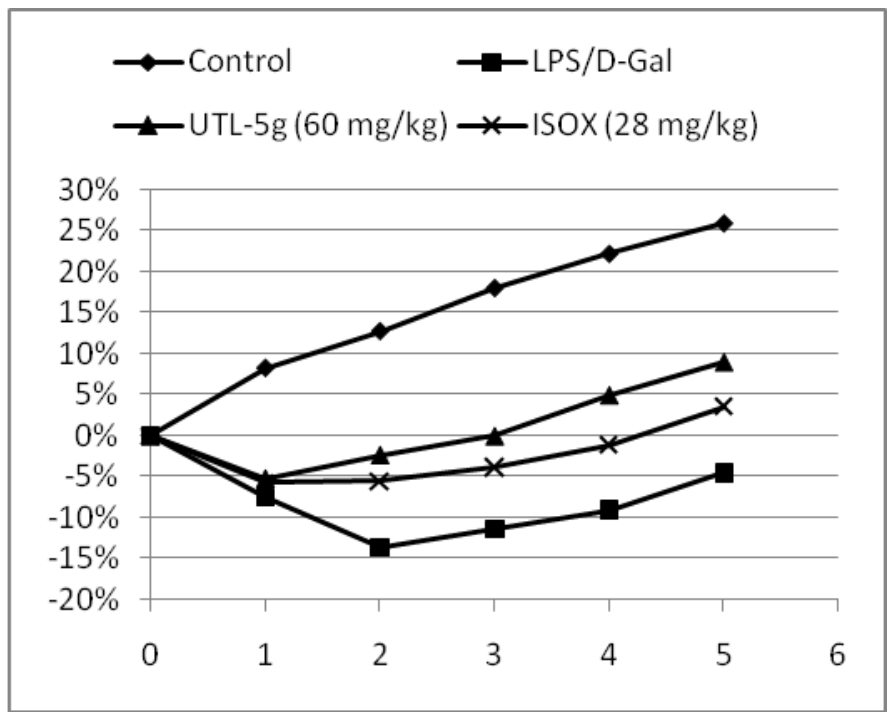

Figure 5. Average body weights for mice with and without pretreatment of UTL-5g and Isox

(a) comparison of the weight loss profiles of Control, LPS/D-Gal, UTL-5g at $30 \mathrm{mg} / \mathrm{kg}$ and Isox at 14 $\mathrm{mg} / \mathrm{kg}$ (equal to UTL-5g in molar conc); (b) comparison of the weight loss profiles of Control, LPS/D-Gal, UTL-5g at $60 \mathrm{mg} / \mathrm{kg}$ and Isox at 28 $\mathrm{mg} / \mathrm{kg}$ (equal to UTL-5g in molar concentration)

\subsection{Animal study \#4}

As shown in Fig. 6, the final study demonstrated that TNF- $\alpha$ levels elevated by LPS/D-Gal (from 471 to $1782 \mathrm{ng} / \mathrm{mL}$ ) were lowered by both UTL-5g and by Isox; essentially the same effects by UTL-5g and by Isox were observed for TGF- $\beta$ although the reduction of TGF- $\beta$ by Isox at $28 \mathrm{mg} / \mathrm{kg}$ was less than that at $14 \mathrm{mg} / \mathrm{kg}$. In addition, the reductions of both TNF- $\alpha$ and TGF- $\beta$ are generally parallel to the mouse survival pattern in the previous study.

(a)

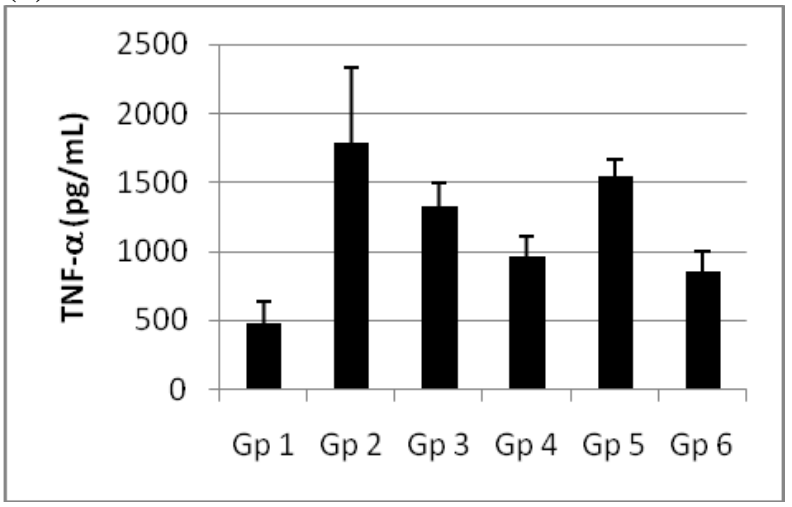

(b)

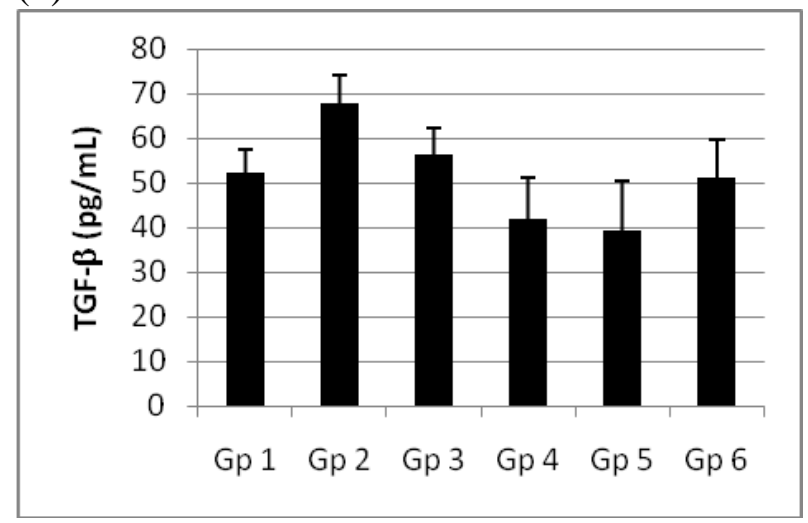

Figure 6. Plasma levels of TNF- $\alpha$ and TGF- $\beta$ in mice with and without pretreatment of UTL- $5 \mathrm{~g} / \mathrm{Isox}$ Gp 1, vehicle control; Gp 2, LPS/D-Gal; Gp 3, UTL$5 \mathrm{~g} 30 \mathrm{mg} / \mathrm{kg}+$ LPS/D-Gal; Gp 4, UTL-5g $60 \mathrm{mg} / \mathrm{kg}+$ LPS/D-Gal; Gp 5, Isox 14 mg/kg + LPS/D-Gal; Gp 6, Isox $28 \mathrm{mg} / \mathrm{kg}+$ LPS/D-Gal. For both TNF- $\alpha$ and TGF- $\beta$ levels, $p<0.05$ for Gp 2 vs. Gp 4. For Fig 6a, $\mathrm{n}=5$ for all groups; for Fig $6 \mathrm{~b}, \mathrm{n}=5$ for Gp $2 \& 6, \mathrm{n}$ $=4$ for $\mathrm{Gp} 1,3 \& 4$, and $\mathrm{n}=3$ for $\mathrm{Gp} 5$ due to insufficient plasma available. 


\section{Discussion}

Results from the first animal study showed that both UTL-5g and Isox protected mice from the lethal toxicity induced by LPS/D-gal, but DCA had no protective effect against the lethality. The ability of both UTL-5g and Isox to increase mouse survival could be due to TNF- $\alpha$ inhibition at least in part because similar protective observations were reported previously for a structurally similar TNF- $\alpha$ inhibitor, UTL$5 \mathrm{~b}$ [14]. In addition, UTL-5g is known to be quickly metabolized to produce Isox [7]. Therefore, it was not surprising to see that Isox also showed significant protective effect. However, in this first study, more animals survived under the treatment of Isox than under UTL-5g. This could be due to two additive factors: (1) Although the doses were the same, both at $60 \mathrm{mg} / \mathrm{kg}$, the difference in molecular weights of UTL-5g and Isox (271 vs. 127) makes the effective molar conentration of Isox > 2 times higher than that of UTL-5g; (2) Although both UTL-5g and Isox were prepared in 1\% CMC, UTL-5g stayed as a suspension whereas Isox was completely dissolved in 1\% CMC; this could have resulted in a much lower oral bioavailability of UTL-5g as compared to Isox. Thus in the second animal study, both UTL-5g and Isox were administered by i.p. injection instead of oral administration.

Results from the second study again indicate that both UTL-5g and Isox protected mice treated with LPS/D-gal, but UTL-5g was more potent than Isox by i.p. injection at the same dose of 30 $\mathrm{mg} / \mathrm{kg}$. This observation supports our hypothesis that UTL-5g is both an active drug and a prodrug with Isox as the active metabolite of UTL-5g. We also used body weight as a general toxicity marker; indeed, UTL-5g lessened the weight-loss effect from LPS/D-Gal indicating its general protective effect against the toxicity induced by LPS/D-Gal. However, Isox did not lessen the weight-loss effect significantly.

The third animal study (Fig. 4) showed that UTL-5g protection of animals from the lethal toxicity (shown by the survival increase) was dose dependent. Although Isox also showed protective effect against the lethality induced by
LPS/D-Gal, Isox was not as effective as UTL-5g at the same molar concentration further indicating that UTL-5g is likely both an active drug and a prodrug. Thus, it may be advantageous to use UTL-5g rather than Isox as a potential protective agent. As to the body weights, at $0.11 \mathrm{mMole} / \mathrm{kg}$ (Fig. 5a), UTL-5g group did not lose weight and started to gain weight from Day 2. At a higher dose of $0.22 \mathrm{mMole} / \mathrm{kg}$ (Fig. 5b), UTL-5g might have some negative effect itself in protecting body weight. Overall, UTL-5g and Isox both showed protective effect in body weight but UTL-5g is more effective.

The final study demonstrated that plasma levels of both TNF- $\alpha$ and TGF- $\beta$ elevated by LPS/D-Gal were lowered by either UTL-5g or Isox although the reduction of TGF- $\beta$ by Isox was not statistically significant. In addition, the reductions of both TNF- $\alpha$ and TGF- $\beta$ are generally parallel to the mouse survival pattern in the previous study. This is logical because LPSinduced up-regulation of TGF- $\beta$ receptor is associated with TNF- $\alpha$ expression and blockade of TGF- $\beta$ signaling reduces the production of TNF- $\alpha$ [22]. In addition, elevated TNF- $\alpha$ levels induced by LPS are known to be associated with animal lethality [14, 23]. The only odd observation is that Isox at $14 \mathrm{mg} / \mathrm{kg}$ seemed to have a little better effect as compared to Isox 28 $\mathrm{mg} / \mathrm{kg}$, which can be seen in both the survival rates and the lowering of TGF- $\beta$ levels, however, the difference is not statistically significant and could be partially due to experimental deviations.

It has been reported that both TNF- $\alpha$ and TGF- $\beta$ levels are elevated in patients with sepsis [24-26]. In addition, blockade of TGF- $\beta$ signaling significantly reduces the production of TNF- $\alpha$ by LPS-stimulated human monocyte-derived macrophages [22]. The present work on UTL-5g is in line with these reports and indicates that UTL-5g may be worthy of further investigation as a potential agent for sepsis.

This current study further expands the protective effects of UTL-5g in addition to our previous studies which showed that UTL-5g is chemoprotective and radioprotective. This work shows that UTL-5g increases the survival rates of mice treated by LPS/D-gal and its protective effects are related to the reduction of TNF- $\alpha$ / 
TGF- $\beta$ levels elevated by LPS/D-Gal. This is consistent with what we observed previously in the protective effect of UTL-5g against the toxicity of cisplatin in that elevated TNF- $\alpha$ levels were also lowered by UTL-5g [6]. Furthermore, our previous studies showed that a closely related TNF- $\alpha$ inhibitor, UTL-5b, significantly suppresses three genes that are relevant to the TNF- $\alpha$ pathway: Janus kinase 3 (JAK3), mitogen-activated protein kinase kinase kinase 2 (MAP3K2) and LPS-induced TNF- $\alpha$ factor (LITAF) [13, 14]. Based on the almost identical structural similarity between UTL-5g and UTL$5 \mathrm{~b}$, we believe that the mechanism of UTL-5g may be similar although the theory remains to be further verified.

Because Isox is an active metabolite of UTL$5 \mathrm{~g}$, it can be concluded that UTL-5g is also a prodrug. This conclusion is further supported by the facile conversion of UTL-5g into Isox [7]. However, Isox is not as potent as UTL-5g based on molecular concentration indicating that UTL$5 \mathrm{~g}$ is also an active drug.

In summary, coupled with the chemoprotective effects of UTL-5g against cisplatin-induced side effects in kidney, liver, and platelets, as well as the radioprotective effects of UTL-5g in liver and lung, this study expands the protective range of UTL-5g potentially to LPS related diseases including sepsis [27, 28] and other immune-mediated diseases [29-31].

\section{Acknowledgement}

This work was supported by grants from National Institutes of Health, 2R44CA141749-02, and from Sichuan Science and Technology Support Plan, 2013-2015, No.2013SZ0049.

\section{References}

1. WHO, Leflunomide: haematologic,hepatic and respiratory reactions. WHO Drug Information, 2002. 16: p. 205-68.

2. Shankaranarayana, s., C. Barrett, and P. Kubler, The Safety of Leflunomide. Australian Prescriber, 2012. 36(1): p. 28-32.

3. Balague, C., et al., Profiling of dihydroorotate dehydrogenase, p38 and JAK inhibitors in the rat adjuvant-induced arthritis model: a translational study. $\mathrm{Br} \mathrm{J}$ Pharmacol, 2012. 166(4): p. 1320-32. DOI: 10.1111/j.1476-5381.2012.01836.x

4. Brent, R.L., Teratogen update: reproductive risks of leflunomide (Arava); a pyrimidine synthesis inhibitor: counseling women taking leflunomide before or during pregnancy and men taking leflunomide who are contemplating fathering a child. Teratology, 2001. 63(2): p. 106-12. DOI 1002/10969926(200102)63:2<106::AIDTERA1017>3.0.CO;2-R

5. Sevilla-Mantilla, C., et al., Leflunomideinduced acute hepatitis. Dig Liver Dis, 2004. 36(1): p. 82-4. doi: 10.1016/j.dld.2003.06.002

6. Shaw, J., et al., The small-molecule TNFalpha modulator, UTL-5g, reduces side effects induced by cisplatin and enhances the therapeutic effect of cisplatin in vivo. J Exp Ther Oncol, 2011. 9(2): p. 129-37.

7. Swartz, K., et al., Using a simple HPLC approach to identify the enzymatic products of UTL-5g, a small molecule TNF-alpha inhibitor, from porcine esterase and from rabbit esterase. J Chromatogr $\mathrm{B}$ Analyt Technol Biomed Life Sci, 2013. 940: p. 1-6. DOI: 10.1016/j.jchromb.2013.09.021

8. Shaw, J., et al., Metabolism studies of a small-molecule tumor necrosis factor-alpha (TNF-alpha) inhibitor, UTL-5b (GBL-5b). Eur J Drug Metab Pharmacokinet, 2012. 37(2): p. 83-9. DOI: 10.1007/s13318-011$\underline{0072-7}$

9. Song, Y., et al., Comparison of Two Molecular Scaffolds, 5-Methylisoxazole-3Carboxamide and 5-Methylisoxazole-4Carboxamide. Curr Pharm Des, 2013. 
10. FDA. NDA 20905 Clinical Pharmacology and Biopharmaceutics Review(s). 1998 [cited 2013 February22, 2013]; Available from: http://www.fda.gov/ohrms/dockets/dockets/0 5p0127/05p-0127-cp00001-Tab-02-NDAvol1.pdf.

11. Breedveld, F.C. and J.M. Dayer, Leflunomide: mode of action in the treatment of rheumatoid arthritis. Ann Rheum Dis, 2000. 59(11): p. 841-9. DOI: 10.1136/ard.59.11.841

12. Fox, R.I., Mechanism of action of leflunomide in rheumatoid arthritis. J Rheumatol Suppl, 1998. 53: p. 20-6.

13. Shaw, J., et al., A Novel Leflunomide Analog, UTL-5b (GBL-5b), Suppresses JAK3, MAP3K2, and LITAF Genes. Am J Biomed Sci, 2011. 3(3): p. 218-227.

14. Shaw, J., et al., Anti-inflammatory and Antiarthritic Effects of a Novel Leflunomide Analogue, UTL-5b (GBL-5b). Am J Biomed Sci, 2011. 3(1): p. 31-39.

15. Shaw, J., et al., The small-molecule TNFalpha inhibitor, UTL-5g, delays deaths and increases survival rates for mice treated with high doses of cisplatin. Cancer Chemother Pharmacol, 2013. 72(3): p. 703-7. DOI: 10.1007/s00280-013-2236-4

16. Shaw, J., et al., Pretreatment with a SmallMolecule Tumor Necrosis Factor-Alpha (TNF-á) Inhibitor, UTL-5g, Reduced Radiation-Induced Acute Liver Toxicity in Mice. American Journalof Biomedical Sciences, 2012. 4(2): p. 123-131. DOI: $\underline{10.5099 / a j 120200123}$

17. FDA. Prescribing information,warnings of hepatotoxicity. 2003; Available from: http://www.fda.gov/downloads/Safety/MedW atch/SafetyInformation/SafetyAlertsforHuma nMedicalProducts/UCM168409.pdf.

18. Gupta, R., J. Bhatia, and S.K. Gupta, Risk of hepatotoxicity with add-on leflunomide in rheumatoid arthritis patients. Arzneimittelforschung, 2011. 61(5): p. 312-6. DOI: $10.1055 / \mathrm{s}-0031-1296204$

19. Levy, E., et al., Distinct roles of TLR4 and CD14 in LPS-induced inflammatory responses of neonates. Pediatr Res, 2009.
66(2): p. 179-84. DOI: 10.1203/PDR.0b013e3181a9f41b

20. Wright, S.D., et al., CD14, a receptor for complexes of lipopolysaccharide (LPS) and LPS binding protein. Science, 1990. 249(4975): p. 1431-3. DOI: 10.1126/science. 1698311

21. Villa, P. and P. Ghezzi, Animal models of endotoxic shock. Methods Mol Med, 2004. 98: p. 199-206.

22. Chen, Y., et al., LPS-induced up-regulation of TGF-beta receptor 1 is associated with TNFalpha expression in human monocyte-derived macrophages. J Leukoc Biol, 2008. 83(5): p. 1165-73. DOI: $10.1189 /$ jlb.0807521

23. Tateda, K., et al., Lipopolysaccharideinduced lethality and cytokine production in aged mice. Infect Immun, 1996. 64(3): p. 769-74.

24. Marie, C., J.M. Cavaillon, and M.R. Losser, Elevated levels of circulating transforming growth factor-beta 1 in patients with the sepsis syndrome. Ann Intern Med, 1996. 125(6): p. 520-1. DOI: 10.7326/0003-4819125-6-199609150-00034

25. Rigato, O., et al., Tumor necrosis factor alpha (TNF-alpha) and sepsis: evidence for a role in host defense. Infection, 1996. 24(4): p. 314-8. DOI: 10.1007/BF01743367

26. Blackwell, T.S. and J.W. Christman, Sepsis and cytokines: current status. Br J Anaesth, 1996. 77(1): p. 110-7. DOI: $10.1093 / \mathrm{bja} / 77.1 .110$

27. Opal, S.M., et al., Relationship between plasma levels of lipopolysaccharide (LPS) and LPS-binding protein in patients with severe sepsis and septic shock. J Infect Dis, 1999. 180(5): p. 1584-9. doi: 10.1086/315093

28. Shapira, L., et al., Protection against endotoxic shock and lipopolysaccharideinduced local inflammation by tetracycline: correlation with inhibition of cytokine secretion. Infect Immun, 1996. 64(3): p. 8258.

29. Charalambous, B.M., et al., Role of bacterial endotoxin in chronic heart failure: the gut of the matter. Shock, 2007. 28(1): p. 15-23. DOI: $10.1097 /$ shk.0b013e318033ebc5 
30. Cavallo, T. and N.A. Granholm, Bacterial lipopolysaccharide induces long-lasting IgA deficiency concurrently with features of polyclonal $B$ cell activation in normal and in lupus-prone mice. Clin Exp Immunol, 1991. 84(1): p. 134-8.

31. Yoshino, S. and M. Ohsawa, The role of lipopolysaccharide injected systemically in the reactivation of collagen-induced arthritis in mice. $\mathrm{Br} \mathrm{J}$ Pharmacol, 2000. 129(7): $\mathrm{p}$. 1309-14. doi: 10.1038/sj.bjp.0703166 